\title{
Live controls for radioisotope tracer food chain experiments using meiofauna*
}

\author{
Paul A. Montagna \\ Belle W. Baruch Institute for Marine Biology and Coastal Research and Department of Biology, University of South Carolina, \\ Columbia, South Carolina 29208, USA
}

\begin{abstract}
Formalin poisoned samples are inadequate for measuring the amount of label to be subtracted as control values for certain food chain studies that employ radioactive tracers. In some studies, tracer is added just before incubation to label 'food' during the feeding study. Commonly, parallel, poisoned incubations are used to distinguish between biotic and abiotic label incorporation. But, a poisoned control does not account for label that could enter a consumer via active transport, epicuticular microfloral uptake, or grazing on labeled, non-food particles. Experiments were performed to test if label uptake is greater in live non-grazing than dead organisms. Marine benthic meiofauna incoporate from 3 to 133 times more tracer when they are alive and not grazing than when they are formalin killed. These results suggest that control experiments with live animals be performed to measure all processes by which label can enter consumers in food chain experiments.
\end{abstract}

\section{INTRODUCTION}

Food chain studies that employ radioactive tracer techniques label potential food items by either labeling food before, or during, the incubation period. It is relatively easy to add tracers to freshly collected samples and follow the movement of the tracer through the various food chain compartments (Daro, 1978; MeyerReil and Faubel, 1980). This technique is very easy to apply and particularly useful if one wants to measure the impact of grazing in situ (Daro, 1978; Roman and Rublee, 1981).

When tracer is added just prior to incubation in a food chain experiment a parallel, poisoned, control sample is usually run simultaneously to correct for abiotic adsorption of label by the grazing animals. Formalin (Roman and Rublee, 1981) and Bouin fixative (Meyer-Reil and Faubel, 1980) have been used as poison in these types of control experiments. However, poisoned controls have been criticized in other types of experiments where it is necessary to separate biotic and abiotic processes (Brock, 1978). For example, formalin controls are inadequate for distinguishing between aerobic metabolism and non-biological oxidation (Pamatmat, 1977). Therefore, it is necessary to

\footnotetext{
- Contribution No. 487 from the Belle W. Baruch Institute for Marine Biology and Coastal Research
}

ask if a poisoned control is adequate in accounting for all label that enters a consumer save grazing.

Bacteria (Simidu et al., 1971) and diatoms (Tietjen, 1971) are known to live as ectocommensals attached to animals that might eat both bacteria and diatoms. Thus, it may be necessary to account for uptake by the epiflora on the consumers cuticle. Marine invertebrates are also known to absorb dissolved organic compounds by epidermal transport (Stewart, 1979; Stephens, 1982). If radioactive organics are used to label bacterial food, a poisoned control would not account for label that entered the consumer via active absorption. Although non-feeding animals do not drink, label may enter the mouth during feeding and adsorb, absorb, or diffuse into the gut during feeding (Gomme, 1982). So, label may enter a consumer organism in a variety of ways: (1) in particulate form, i.e. grazing labeled food, or grazing particles on which label has adsorped; (2) in dissolved form, i.e. diffusion or active uptake of label across the cuticle; adsorption of label to cuticle; drinking of label and absorption of label by the gut; and/or uptake of label by microbes attached to the cuticle. In food chain studies where herbivorous (or bactivorous) behavior is of interest, a control value must subtract the appropriate number of radioactive counts for all activities other than grazing on labeled food. Formalin controls would only account for label that is adsorbed on, or had diffused into, an 
animal. The sum of the processes by which added label can enter a grazing animal can only be measured in a control experiment using live animals.

The purpose of this study is to assess the adequacy of poisoned controls in a benthic food chain experiment. This was accomplished by measuring the incorporation of label by live meiofauna in a non-feeding environment and comparing it to formalin killed meiofauna.

\section{MATERIAL AND METHODS}

Benthic meiofauna were extracted from muddy saltmarsh sediments at the Belle W. Baruch Institute's field laboratory near Georgetown, South Carolina, USA $\left(33^{\circ} 20.0^{\prime} \mathrm{N}, 79^{\circ} 10.0^{\prime} \mathrm{W}\right)$. The animals used in the experiments were hand-sorted from the sediment and rinsed 3 times in filter sterilized $(0.2 \mu \mathrm{m})$ artificial sea water (25\% S, Instant Ocean). For live treatments meiofauna were placed in sterile petri dishes containing $15 \mathrm{ml}$ sterile Instant Ocean (SIO), tracer was added as detailed below, and the dish incubated for $4 \mathrm{~h}$ at $20^{\circ} \mathrm{C}$. Since no food (either diatoms or bacteria) was present and label could not enter an animal as a labeled food particle, the experiments measured meiofaunal incorporation of soluble label in a nongrazing circumstance.

Table 1. Data for glucose live control experiment. Uptake of ${ }^{14} \mathrm{C}$-glucose (DPM individual ${ }^{-1}$ ) by non-feeding live and dead meiofauna at 2 concentration levels

\begin{tabular}{|lccrc|}
\hline \multirow{2}{*}{ Meiofauna } & \multicolumn{4}{c}{ Concentration } \\
& $0.004 \mu \mathrm{Ci} \mathrm{ml}^{-1}$ & $0.028 \mu \mathrm{Ci} \mathrm{ml}^{-1}$ \\
& Live & Dead & Live & Dead \\
\hline Nematodes & 0.55 & 0.07 & 11.3 & 1.9 \\
& 0.45 & 0.08 & 10.5 & \\
Copepods & 0.83 & 0.11 & 4.8 & 0.6 \\
& 0.63 & 0.08 & 5.5 & \\
Polychaetes & 6.35 & 2.24 & 10.0 & 4.6 \\
Ostracods & & & 20.2 & \\
& & & 35.1 & 1.6 \\
& & & 22.6 & \\
\hline
\end{tabular}

Table 2. ANOVA table for the ${ }^{14} \mathrm{C}$-glucose incorporation experiment. Main effects are the 2 treatments (live vs. dead), 4 taxa (copepods, ostracods, nematodes, and polychaetes), and 2 substrate concentrations

\begin{tabular}{|lrrrr|}
\hline Source & df & \multicolumn{1}{c}{ MS } & \multicolumn{1}{c}{ F } & $P$ \\
\hline Concentration & 1 & 175.45 & 10.76 & 0.0112 \\
Taxa & 3 & 65.65 & 3.98 & 0.0526 \\
Treatment & 1 & 318.14 & 19.50 & 0.0022 \\
Interaction & 8 & 49.26 & 3.02 & 0.0694 \\
Error & 8 & 16.31 & & \\
\hline
\end{tabular}

After the incubation period the live treatments were stopped by adding $1 \mathrm{ml}$ of $4 \%$ formaldehyde solution. Dead treatments were set up exactly as the live treatments except that formaldehyde solution was added before the tracer. Animals from both live and dead treatments were sieved and sorted into separate scintillation vials by taxa. The meiofauna were solubilized with $1 \mathrm{ml}$ of Packard Soluene 100 for $24 \mathrm{~h}$, and counted in a Packard Liquid Scintillation Counter, using Packard Insta-gel as a cocktail. Quenching was corrected by using external standards.

${ }^{14} \mathrm{C}$-glucose (specific activity $=329 \mathrm{mCi} \mathrm{mmol}^{-1}$ ) was obtained from New England Nuclear, and diluted in SIO. Glucose tracer was added at 2 concentrations

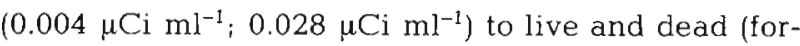
maldehyde poisoned) meiofauna in replicate as detailed above. Although the same number of meiofauna were used in each treatment, recovery was variable; each treatment contained the following num. bers of meiofauna taxa (mean \pm standard error): copepods $(51 \pm 15)$, nematodes $(86 \pm 39)$, ostracods $(16 \pm 2)$ and polychaetes $(11 \pm 8)$.

$\mathrm{NaH}^{14} \mathrm{CO}_{3}$ (specific activity $=7.0 \mathrm{mCi} \mathrm{mmol}{ }^{-1}$ ) obtained from New England Nuclear was filtered to remove inorganic particulate contamination and diluted in SIO. Two experiments were performed, each at a different final concentration $(0.0625 ; 0.25 \mu \mathrm{Ci}$ $\mathrm{ml}^{-1}$ ), as described above. Each experiment contained the 2 treatments (1) live and (2) dead (formalin poisoned) meiofauna; but were not replicated. The following numbers of meiofauna were recovered in each treatment: $88( \pm 8)$ copepods, 67 (士10) nematodes, and $15( \pm 5)$ polychaetes.

The dependent variable measured in the experiments was uptake of tracer (DPM individual ${ }^{-1}$ ). There are 3 independent variables in each experiment: treatment, meiofauna taxa and substrate concentration. Of particular interest here is labeling of the meiofaunal community under different treatments (i.e. alive vs. formalin killed). Due to the excessive time required to sort and clean the meiofauna the experiments at different concentrations were performed on different days. Thus, differences due to concentration and separate days are confounded. A 3-way analysis of variance (ANOVA) and Statistical Analysis System (SAS) software were used for the data analyses (Helwig and Council, 1979).

\section{RESULTS}

Results of the glucose uptake experiment are shown in Table 1. In the glucose experiment there was no significant 3 -way interaction $(P=0.0694$; Table 2$)$. There was a significant difference in uptake of glucose 
between live and dead meiofauna ( $P=0.0022$; Table $2) ;$ live meiofauna incorporated 10.7 ( \pm 1.7 ) DPM individual $^{-1}$, compared to 3.6 ( \pm 2.0 ) for dead meiofauna (Table 1). Although there were differences in glucose label uptake between the 4 meiofauna taxa (Table 1), the differences were barely significant $(P=0.0526$; Table 2). The experiments were not designed to examine uptake differences among the meiofaunal taxa, and the biomass adjusted uptake might yield different results than obtained here. There was higher uptake of label at the higher concentration $(P=$ 0.0112 ; Table 2).

Interaction could not be tested in the bicarbonate uptake experiment since no replicates were performed (Table 3). Live meiofauna incorporated more labeled bicarbonate (232 DPM individual $\left.{ }^{-1}\right)$ than dead meiofauna (43), but not at a significant level $(P=$ 0.1111 ; Table 4). However, bicarbonate uptake was greater in the live than dead samples in 5 of 6 cases (Table 3). The lack of statistical significance was due to one anomolous result, polychaetes at $0.0625 \mu \mathrm{Ci} \mathrm{ml}{ }^{-1}$. In general the results suggest that bicarbonate uptake by live animals is greater than that in dead meiofauna. Among the meiofauna studied polychaetes incorporated the highest amount of bicarbonate tracer (205 $\mathrm{DPM}_{\text {individual }}{ }^{-1}$ ) in comparison to copepods (173) or nematodes (36).

\section{DISCUSSION}

Experiments with both radioactive glucose and bicarbonate demonstrate that non-feeding live animals can incorporate more tracer than dead animals. In food chain experiments bicarbonate is usually used to label autotrophs, and glucose is sometimes used to label heterotrophs. If tracer is added just before incubation to label 'food' during the incubation period, then a poisoned control will underestimate the amount of tracer that is incorporated into the consumer save feeding activities. Thus, incorporation due to feeding will be overestimated.

The ability of soft-bodied marine invertebrates to absorb dissolved organic matter (DOM) is well known in polychaetes, bivalves, and echinoderms. In all these organisms absorption is by epidermal tissues, and is a saturable process (Stewart, 1979). Therefore, when DOM is added to label bacteria as food, the uptake of DOM by invertebrates is an important process to measure and must be subtracted as a control value in any food chain experiment. In herbivory experiments where dissolved inorganic carbon (DIC) is used to label photosynthetically active food a live control is also necessary. I am not aware of literature that suggests invertebrates can transport DIC across their
Table 3. Data for bicarbonate control experiment. Uptake of ${ }^{14} \mathrm{C}$-bicarbonate (DPM individual ${ }^{-1}$ ) by non-feeding live and dead meiofauna at 2 concentrations

\begin{tabular}{|lcccc|}
\hline \multirow{2}{*}{ Meiofauna } & \multicolumn{5}{c|}{ Concentration } \\
& $\begin{array}{c}0.0625 \mu \mathrm{Ci} \mathrm{ml}^{-1} \\
\text { Live }\end{array}$ & Dead & \multicolumn{2}{l|}{$0.25 \mu \mathrm{Ci} \mathrm{m} \mathrm{ml}^{-1}$} \\
& Live & Dead \\
\hline Nematodes & 10 & 2 & 126 & 6 \\
Copepods & 19 & 1 & 666 & 5 \\
Polychaetes & 35 & 57 & 537 & 190 \\
\hline
\end{tabular}

epidermis, but, perhaps they 'drink' label as they feed (Gomme, 1982).

The manner of performing a live control experiment needs exploration. In the present study I simply isolated the consumer organisms in a sterile environment so that label would be present but the animal could not feed on labeled food. I did not measure grazing on nonfood particles that might have adsorbed label. This might be measured by adding a metabolic inhibitor to block label uptake by the prey organisms, thus, leaving only non-food particles labeled. Antibiotics could

Table 4. ANOVA table for ${ }^{14} \mathrm{C}$-bicarbonate incorporation experiment. Main effects are the 2 treatments (live vs. dead), the 3 taxa tested (copepods, nematodes, polychaetes), and the 2 concentrations employed. Since replicates were not performed interaction cannot be tested

\begin{tabular}{|lrrrc|}
\hline \multicolumn{1}{|c}{ Source } & df & \multicolumn{1}{c}{ MS } & F & $P$ \\
\hline Concentration & 1 & 164,096 & 5.10 & 0.0585 \\
Taxa & 2 & 32,225 & 1.00 & 0.4147 \\
Treatment & 1 & 106,983 & 3.32 & 0.1111 \\
Error & 7 & 32,196 & & \\
\hline
\end{tabular}

be used in bactivory experiments. However, antibiotics are known to have a lethal effect on such small and ubiquitous metazoans as nematodes (Tietjen and Lee, $1973,1975)$. For herbivory experiments DCMU [3, $(3,4-$ dichlorophenyl)-1, 1-dimethylurea] could be used to block photosynthesis (Golterman, 1971). Alternatively, dark incubation could be used in place of a photosynthetic block as control. Dark fixation is not a dead process but may behave like one (Hopner Petersen, 1979). Any method which would selectively block uptake by the 'food' organism would be an adequate live control. Alternatively, formalin poisoned samples could be used with the live control experiments described here to determine the percent of label fixed by abiotic processes and that portion could then be subtracted from consumer incorporation to reflect grazing on non-food labeled particles. 
Acknowledgements. This paper was extracted from a dissertation submitted as partial fulfillment for the $\mathrm{Ph}$. D. at the University of South Carolina, USA. Financial support was provided by the Belle W. Baruch Institute for Marine Biology and Coastal Research, the Department of Biology, University of South Carolina, and the Biological Oceanography Program of the National Science Foundation (Grant OCE-8007968: B. C. Coulh, principal investigator). I thank B. C. Coull, R. J. Feller, H. N. McKeller, D. L. Wethey, and D. C. Yoch for their helpful comments during the preparation of this manuscript.

\section{LITERATURE CITED}

Brock, T. D. (1978). The poisoned control in biogeochemical investigations. In: W. E. Krumbein (ed.) Environmental biogeochemistry and geomicrobiology, Vol. 3. Ann Arbor Science, Ann Arbor, p. 717-725

Daro, M. H. (1978). A simplified ${ }^{14} \mathrm{C}$ method for grazing measurements on natural planktonic populations. Helgoländer wiss. Meeresunters. 13: 241-248

Golterman, H. L. (1971). The determination of mineralization losses in correlation with the estimation of net primary production with the oxygen method and chemical inhibitors. Freshwat. Biol. 1: 249-256

Gomme, J. (1982). Epidermal nutrient absorbtion in marine invertebrates: a comparative analysis. Am. Zool. 22: $691-708$

Helwig, J. T., Council, K. A. (eds.) (1979). SAS user's guide. SAS Institute, Cary, North Carolina
Hopner Petersen, G. (1979). On the analysis of dark fixation in primary production computations. J. Cons. int. Explor. Mer 38: 326-330

Meyer-Reil, L.-A., Faubel, A. (1980). Uptake of organic matter by meiofauna organisms and interrelationships with bacteria. Mar. Ecol. Prog. Ser. 3: 251-246

Pamatmat, M. M. (1977). Benthic community metabolism: a review and assessment of present status and outlook. In: Coull, B. C. (ed.) Ecology of marine benthos. University of South Carolina Press, p. 89-111

Roman, M. R., Rublee, P. A. (1981). A method to determine in situ zooplankton grazing rates on natural particle assemblages. Mar. Biol. 65: 303-309

Simidu, U., Ashino, K., Kaneko, E. (1971). Bacterial flora of phyto- and zooplankton in the inshore water of Japan. Can. J. Microbiol. 17: 1157-1160

Stephens, G. C. (1982). Recent progress in the study of 'Die Emährung der Wassertiere und der Stoffhaushalt der Gewässer'. Am. Zool. 22: 611-619

Stewart, M. G. (1979). Absorption of dissolved organic nutrients by marine invertebrates. Oceanogr. mar. biol. A. Rev. 17: 163-192

Tietjen, J. H. (1971). Pennate diatoms as ectocommensals of free-living marine nematodes. Oecologia 8: 135-138

Tietjen, J. H., Lee, J. J. (1973). Life history and feeding habits of the marine nematode, Chromadora macrolaimoides Steiner. Oecologia 12: 303-314

Tietjen, J. H., Lee, J. J. (1975). Axenic culture and uptake of dissolved organic substances by the marine nematode, Rhabditis marina Bastian. Cah. Biol. mar. 16: 685-694

This paper was submitted to the editor; it was accepted for printing on February 5, 1983 